\title{
Nations, Tribes, Peoples, and States ${ }^{1}$
}

\author{
Susan Reynolds*
}

In recent years, there has been considerable debate on whether the term snation « can be applied to kingdoms or states of the Latin West. Nationalist movements are indeed a modern phenomenon, and medieval kingdoms and polities differed from modern states in many organisational and administrative respects. But, as argued here, the medieval kingdoms were independent states and shared key features of what are now called nation-states, creating allegiances notionally defined by custom, law, and descent. Thus, this contribution addresses the words and concepts that framed these allegiances, and their changes over time.

Keywords: nations; states; tribes; political organisation; medieval Europe.

Nations: I start with the word. Its everyday use varies: it is often applied to what I would rather call sstates،. What are called international relations are relations between states. The United Nations is an association of states, that is, areas under independent governments, but the newly independent states of North America had appropriated the title of >United States long before the UN started, so the UN could not use it. English, unlike German, has another confusion as we call the process of Verstaatlichen snationalization<. The everyday use of words and their meanings cannot be controlled. If we want to discuss nations and their history, we need to start by thinking what each of us means by words in our own languages and whether we understand each other's meanings, especially if we want to make comparisons between different periods of history, different languages and countries (another word used in various quite different senses), and even maybe different disciplines. I cannot say what is the right use of the word and nor can anyone. I can only say what I mean by it.

So, by nation I mean a section of human society, generally one which is, or once was, a unit of government which those within it, or some of them, believe is a natural community that, if it is not an independent state, they think ought to be an independent state. The belief in a natural community is often based on ideas or myths of their common biological descent and of a shared history and culture, including common customs and (where it fits) language. Some, however, may think that their nation is a voluntary community which has made or is making its own culture despite the different origins of its members.

I use state for an organization of human society within a more or less fixed area in which the ruler or governing body more or less successfully controls the legitimate use of physical force, especially against persons. This is adapted from Max Weber by inserting smore or less because no state is totally successful in controlling its borders or the people inside it, and changing >monopoly< to >control because some states allow individuals to use force on others in ways and circumstances that are considered legitimate in that state. ${ }^{2}$ A state makes its own rules and enforces them.

* Correspondence details: Susan Reynolds, FBA, 19 Ridgmount Gardens, London WC1E 7AR, UK, email: smgreynolds@gmail.com

1 This paper was first presented at the conference "Identity, Ethnicity and Nationhood before Modernity: Old Debates and New Perspectives « at Oxford in April 2015, and has since been edited for publication in this journal.

2 Weber, Wirtschaft und Gesellschaft, 122-125. 
It may help to start our attempt at analysis and mutual comprehension if we distinguish the word which any of us uses in our own language from the notion or concept that one has in one's mind when one uses it, which may well be different from what one's hearer or reader understands by it; and both from the phenomenon either word or concept represents: that is, some actual collective group, past or present, which can better be distinguished from others, irrespective of both word or notion, by describing its characteristics and powers. About forty years ago, when I was struggling with the problem of words, I found the following diagram by Ogden and Richards extremely helpful: ${ }^{3}$

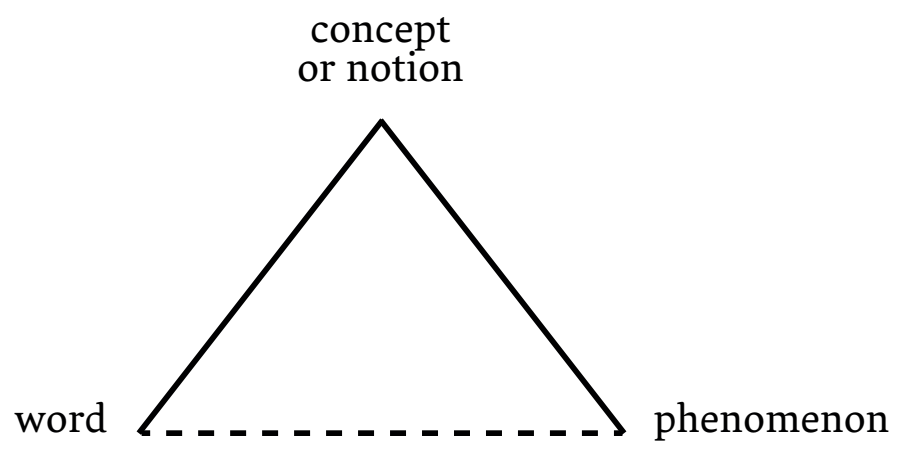

Ruth Schmidt-Wiegand has considered it in connection with associations in medieval German towns. ${ }^{4}$

It is sometimes said that the use of the word state for an independent unit of government is modern, but that does not mean that there could not have been any phenomena that fitted my adaptation of Max Weber's definition before whatever date at which one considers 'modern times to have started. Past governments were different from modern governments, and they were thought about differently, but modern states in any case differ in their government and in the ways people think about them. And the same goes for variations in the word, concept, and phenomenon of the nation - or the tribe.

States are real phenomena - objective facts: we live in them and under their governments, and can be punished according to their laws, irrespective of the word used to denote them or whether anyone has a clear concept of the state. Nations are harder to see as objective facts, since some which are called nations are not even subordinate units of government while people in them may disagree about what nation they belong to: some Bretons think their nation is Brittany, not France; the UK is often called a nation-state and some of its inhabitants think it forms a single nation, but others think it contains three or four distinct nations. Some nations are also states, but some are not. I nevertheless hope that we may agree that a vital characteristic of what is called a nation now is that its members, or some of them, think that it has the right to be a state - that is, an independent unit of government: hence the movements and

3 Ogden and Richards, Meaning of Meaning, 13-15; further discussions in e.g. Lyons, Semantics, 95-119, 175; Tallis, Not Saussure, 114-116.

4 Schmidt-Wiegand, Die Bezeichnungen Zunft und Gilde, 31-52; Schmidt-Wiegand, Historische Onomasiologie und Mittelalterforschung, 49-78; Reynolds, Fiefs and Vassals, 12-14, and more fully in Reynolds, Use of Feudalism. 
wars to achieve that status. Nations are, in Benedict Anderson's words, rimagined communities.$^{5}$ That does not mean that they are or were unimportant or unreal. Belief and imagination can create feelings of community, so as to promote cohesion and unforced obedience, which all states need from at least some of their inhabitants. State and nation may coincide, but they are different.

So much for our (or rather my) words, concepts, and phenomena. When we come to look at those of the past, we all have different amounts of knowledge about different periods and societies. I try to do the history of western Europe in the Middle Ages, but that covers a thousand years, and my knowledge of it is patchy both in chronology and geography. But one thing I am sure about: that medieval people did not always use words consistently or uniformly any more than modern people do: it is even more unrealistic to start from >definitions continents and periods, but most of what I shall say about any bit of history could be corrected by some others. Still, I shall try to set out arguments that I think may be helpful if only in provoking corrections that will advance my knowledge and maybe the knowledge of others, and generally make us all think. I start with some very elementary social anthropology.

Human beings are, by and large, social beings, but their large brains and their use of language make them variable and awkward in their sociability. Even in very small societies of hunter-gatherers (Jäger und Sammler), individuals may develop separate and possibly conflicting desires and interests. They therefore need to practice some sort of politics, in the sense of organizing their collective life and developing rules and customs about it. ${ }^{6}$ Then, in the slightly richer and larger pastoral societies that sometimes develop, men with larger flocks, families and servants or slaves may join with other flock-rulers to develop customs and rules by which they together control and, if necessary, coerce all their families and followers.

Although such small groups have often exercised coercive force according to their norms and customs, most historians do not think of them either as states or as nations, perhaps due to the fact that they look too small and, above all, too sprimitiver. The words tribe, tribus, Stamm etc. seem to have first been applied to what were seen as sprimitiver and spre-stater units of government in the eighteenth century. I avoid them, not only because their use in ordinary conversation is even more variable than that of state or nation, but because the anthropologists who study the phenomena argue among themselves about it. ${ }^{7}$ Maybe we could simply see these small, 'primitiver groups as one kind of speopler, following the Oxford Dictionary's definition of one sense of 'peopler as 'The body of men, women, and children comprising a particular nation, ethnic group, etc.<, with particular emphasis on that retc.< We could then try to focus less on the word and more on the evidence of the distinguishing characteristics of the phenomena we are talking about. ${ }^{8}$

These small societies are sometimes said to be egalitarian. They certainly have lower hierarchies than do larger, richer, and more complex societies, but the equality is often only between senior men who are the heads of relatively large and prosperous households, exclud-

Anderson, Imagined Communities; Friend, Stateless Nations, 2-6.

6 Clastres, Society Against the State; Lapierre, Vivre sans état; Woodburn, Egalitarian Societies, 431-451; Barnard, Hunters and Herders of Southern Africa.

7 Reynolds, Vocabularies for Comparative and Interdisciplinary History.

8 Oxford English Dictionary: people II. 6; On medieval speoplesı: Davies, The Peoples of Britain and Ireland: I-IV. 
ing not only women and servants or slaves, but also maybe the adult sons of the dominant men. ${ }^{9}$ Although most, if not all, of those who belong in this sort of society probably assume the right and duty of such men to coerce the rest when it is thought just, they do not have the resources to coerce everyone all the time. All governments rely on more or less voluntary submission of most of their subjects to most of the rules most of the time. If a society does not have guns and sophisticated means of communication it relies on it even more. Voluntary submission seems often to have been achieved by fostering solidarity and social cohesion. Historians, especially modern historians, sometimes assume that solidarity and unity go along with modern ideas of equality; but solidarity may in some ways be easier to achieve if it goes along with acceptance of inequality and hierarchy.

Solidarity and cohesion are also fostered by ideas of kinship. Some people in any kind of small community I am talking about would have genuinely close biological connections with each other or form them through marriage. Without permanent and official records it is easy to assume more distant links of kinship so as to absorb new groups or individuals. The units, whether you call them social or political, of such societies apparently seem natural, given communities both to their members and neighbours. ${ }^{10}$ Even if they look too small to be called nations, the belief or assumption that they are natural communities is very like the perception of nations. Since humans do not seem to be born with a belief in equality, and the inequalities in these small and poor societies form hierarchies which fit the communities, the hierarchy probably seems natural too. It gives women and even servants or slaves a natural and necessary place in what can seem a natural community to them too.

The bonds that such small societies assume often combine belief in their common kinship with ideas of their common customs, laws, and language. In other words people in them think of themselves as united by both biology and culture. Maybe they are, in a society small and isolated enough to correspond roughly to a breeding population, but the link between physical heredity and features like language that are acquired after birth has often continued to be assumed, even in large and complex societies. This was, and is, a fallacy, since cultural and biological characteristics are transmitted quite differently, but it was difficult to see that before the work of Gregor Mendel was rediscovered in 1900 and the study of genetics began. I cannot go into this here, and maybe need not, since I luckily left the word sracer out of my title. But I might just point out that the past use of that word for a family, a nation, or almost any group or speopler - even sthe human racer - illustrates the way that biological descent and culture were (and sometimes still are) assumed to go together. The word race therefore seems to me best avoided, though its replacement by rethnicity، (along with rethnic<, rethnogenesis<, and all the other ethne words) often seems to reflect the same conflation of biology and culture. Apart from words, moreover, the same conflation still survives in many of the myths treasured in snational histories. Not always: some scholars, like Walter Pohl, now make it quite clear that the conflation that they find in their sources was of ideas in the heads of the peoples they study, not in their own. But the distinction is not always made clearly, if at all.

In small and poor societies social solidarity, voluntary submission, and even harmony may be fairly adequately achieved with the help of ideas of common descent, customs, law, and history, but that becomes harder as societies become richer, larger, and more complex. Agriculture, to start with, brings more wealth and therefore more inequality and more need

9 But for women in early Icelandic society: Miller, >Why is Your Axe so Bloody? , 90-94.

10 For an illustration of the speed with which histories to suit present solidarities can be invented and believed even in the record-keeping twentieth century: Karakasidou, Fields of Wheat. 
for decisions to be enforced according to the society's laws. Whose is any bit of land and who decides whose it is? And what about the rights, obligations, and control of those who work the land? As wealth increases, so then does trade, which involves more mixing of populations, more regulation and more government. Changes in technology, whether in agriculture, industry, transport and communications, or arms and warfare, all tend to make ideas of a common descent, kinship, and history more and more implausible. But they seem to survive wonderfully, becoming more elaborate and recorded, if in more subtle and refined forms, for instance in ideas of national character, in many national histories as they are taught and written today.

For those who believe, as I do, that there were nations in medieval Europe - that is, political units that people thought of very much as they now think of nations - the collapse of the western part of the Roman Empire may be seen as the time of rethnogenesis - the origin of the nations of modern Europe. This is Walter Pohl's field, not mine, and he has written cogently about the whole process and especially about the difficulty of distinguishing between ethnicity and sense of solidarity on the one hand and power politics on the other in the creation of new kingdoms. ${ }^{11}$ Presumptuous as it may be even to say that I reckon that he is absolutely right, I would just like to add that the problem is not merely about which came first or was more important but about how to distinguish them: the formation of a sense of shared ethnicity is in itself political. It implies a solidarity that probably involves organization and management of collective affairs. ${ }^{12}$

What slightly concerns me about ideas of early medieval ethnogenesis is any suggestion that it was permanent or unique. The humans of Europe - and of other parts of Eurasia? have been so good at forming, reshaping, and replacing any kind of what I shall call polities (that is, political units) that ethnogenesis has happened quite often. Some of the kingdoms or lesser lordships that appeared between the fifth and eighth centuries CE did not survive or survived only as subordinate layers of government. Although historians suffer a constant temptation to read their own solidarities into those of the past, especially when writing their own 'nationalk histories, the most nation-like polities of the past were not necessarily those that foreshadow our own, even if a modern state is called by the same name as a past kingdom or other polity.

All through the Middle Ages kingdoms were the archetype of independent polity and were thought to belong to their peoples as much or more as to their kings. In the eleventh century King Conrad II of Germany (soon to be emperor) was said to have reminded the people of Pavia that kingdoms survived their kings, just as ships remained when their captains died. ${ }^{13}$ In 1320 a letter probably written by a servant of the king of Scots, but with approval of the leading nobles of Scotland, stated that they were all descendants of Scythians who had come through the Pillars of Hercules to settle in poor little remote Scotland and would go on fighting for their independence against England even if their king gave up. ${ }^{14}$ Scotland held out 
against England better than Wales, not only because of their different geography and population, but because it was a kingdom. Even Edward I of England admitted that, though he referred to it on occasion as merely a land.

As methods of government developed during the Middle Ages, rulers worked through collective and consultative processes that moulded ethnic solidarities, both at regnal (that is, kingdom) level and at the level of provinces, lordships, counties, and even towns. As the kings of the Franks extended their territories, myths of the common origin of all Franks were extended to embrace everyone within the kingdom that came to be called France. Consultative government and collective solidarity did not imply anything like democracy or even demand for it: most complaints and rebellions by people at the bottom were for justice within the existing hierarchy, and, particularly in towns, for more consultation. Later in the Middle Ages consultation became more systematic, sometimes with elected representatives, but elections were, I think, still designed to represent whole groups or communities rather than numerical majorities of individuals. Stories developed in some European kingdoms of separate origins of nobles and peasants, ${ }^{15}$ but they do not seem to have replaced or even seriously eroded the idea of kingdoms or other units of government as natural political communities composed, not of equals, but of people of different status, all fitting into a natural hierarchy.

City-states, and even towns with only limited rights of self-government, show attributes of this kind of nationhood, with their own myths of common origin. That the common descent of a town's population could be taken for granted, however improbable constant immigration made it, is shown by an explanation of conflicts in Florence: at least one chronicler thought that they happened because Florentines were divided between descendants of noble Romans and rough Fiesolans. ${ }^{16}$ But despite the independence and fame of a few great cities, kingdoms were the archetypes of nations and kings were the archetypes of rulers. Emperors, incidentally, were always kings too. ${ }^{17}$

Leaving aside city-states if you think them too small to count as nations, medieval ideas about kingdoms suggest to me that the idea of a kingdom was very like the modern idea of a nation. If, as I argue, nations exist primarily, if not only, as ideas, then it seems reasonable to call at least some medieval kingdoms nations. England and France are sometimes referred to as the rfirst national monarchies`, while Len Scales has argued cogently for the sense of community in late medieval Germany, despite its political divisions..$^{18}$ If any of them is seen as essentially a new development that may be because they seem to fit into the traditional teleology of their respective textbook histories - though England, of course, is actually not a state. Other medieval polities, like Saxony, or Florence, or even Bernicia, may have been just as vividly perceived at one time or another as natural, given political communities. Teleology does not help us to understand past societies, especially if they left few records.

Although I consider that medieval kingdoms, inside and outside Europe, along with some lordships and city-states, should qualify as nations, I do not argue that there was as yet anything that I would want to call nationalism. The rism « seems to me to imply a movement to achieve independence for what their leaders claim to be natural, given communities. What I think I find in the bits of the Middle Ages that I know anything about, was less 
a movement to achieve independence than an assumption that existing kingdoms were in fact already natural, given communities - in effect what are now called nation-states. Some rebels wanted to replace their kings (and did so), and a few rebellious nobles maybe wanted to make their lordships into independent kingdoms, especially if some memory of past independence survived. On the whole, however, I reckon that existing units of government in Europe - and Asia? - were taken as natural, given communities, though with the usual arguments about borders that are bound to arise when people try to draw hard lines through territories within which people live and communicate together.

I agree therefore that nationalism as a positive movement seems to date from the eighteenth century, as most historians of nationalism have maintained. Where I differ from them is that I cannot agree that earlier ethnic groups or what Eric Hobsbawm called sprotonational communities،, had, as he put it, 'no necessary relation with the unit of territorial political organisation which is a crucial criterion of what we understand as a nation< today. ${ }^{19}$ My argument on the contrary is that before the rise of nationalism there was, if anything, a closer connection between the political entity and the sense of community than there has been since. Ethnic communities had been shaped by polities under hierarchical, more or less collectivist, governments. Those polities were therefore, I suggest, more like 'nation-states than are many modern states, since a modern nationalist's nation may merely want to be an independent political unit. I entirely accept the modernists' insistence on a connection between the modern idea of a nation and ideas of equality and popular government, even though actually not all so-called nation-states are democracies and few enjoy equality beyond the ballot box. But modern ideas of equality come from what seems to me a quite separate tradition of thought that developed only from the seventeenth century. It derived societies, law, and property from a ssocial contract « made between separate and equal individuals who would otherwise be in a sstate of nature

This new idea did not kill the old idea of natural, given political communities, even though it came to demand that the structure of government inside them should be changed. Hugo Grotius, who produced what seems to me the best, as well as the first, full account of the state of nature and the social contract, nevertheless still cherished the myth of the free commonwealth of the ancient Batavians who were the ancestors of the free people of Holland. Incidentally, reading his Latin account alongside an English translation made about forty years later, made me even more aware of the problem of connecting words to the ideas behind them. ${ }^{21}$ As for the way that the new and old ideas came to be combined in the eighteenth century, I shall cite three examples that I have used before: Jean-Jacques Rousseau, Thomas Jefferson, and Emmanuel-Joseph Sieyès. ${ }^{22}$

Rousseau's ideas about the state of nature and the social contract, however idiosyncratic, clearly derive from the new paradigm. His ideas about nations equally clearly do not. He thought that peoples or nations had originated as communities of custom and way of life -

19 Hobsbawm, Nations and Nationalism since 1780, 47, also 4, 18, 63; cf. Gellner, Nations and Nationalism, 55; Smith, Nationalism, 80-97.

20 The rest of this paragraph is based on Reynolds, Our Forefathers?, 17-36; Reynolds, Idea of the Nation, 54-66; Reynolds, Before Eminent Domain, 132-138, with references in each.

21 Grotius, Liber de antiquitate reipublicae Batavicae; and Grotius, A Treatise of the Antiquity of the Commonwealth, trans. Woods.

22 Reynolds, Before Eminent Domain, 135-137. 
what might now be called ethnic communities. Although they were now under governments that he thought illegitimate, they had long been political units that, though not always independent, had been regarded as natural and given.

Jefferson started the Declaration of Independence with two paragraphs setting out first the old idea and then the new. His first paragraph refers to peoples endowed by the Laws of Nature and of Nature's God with a political right to separate and independent government, even though the particular speopler he was concerned with had hitherto been inter-connected by spolitical bands s with another. What belonged unambiguously to the new paradigm and needed formal statement in the next paragraph, even though he claimed that it was self-evidently true, was the idea of the equality and rights that all men had had before the institution of government.

Lastly, in what has been called the most celebrated pamphlet of the French Revolution, Sieyès' Qu'est-ce que le tiers état suggests a more elaborate and perhaps more conscious combination of new and old. It declared that the nation was prior to everything, but was formed by individuals joining together so as to have a common or national will, and so could form a government. The nation on which he focused without hesitation was geographically coextensive with the eighteenth-century kingdom of France, though he counted only the Third Estate as its citizens. He thus reshaped the political structure of the nation, but the nation was still France, and could draw on many of its old solidarities, loyalties, and myths.

For all three of them, nations had always existed as political communities, however governed, but they should be governed by their speopler.

New ideas about nations also differed from the old because of a new emphasis on language. This is owed much to Germans, particularly Herder, who was no democrat but expressed clearly the belief that Germans, who spoke German and had once had the greatest kingdom of Europe, the inheritor of the Roman Empire, were a true people despite their current division between many states. Then, as ideas of democracy caught on, the need to educate voters and integrate minorities and immigrants made a common language ever more important. But ideas of nations still involved biological descent. Despite the invitation written on the Statue of Liberty to the huddled masses of the poor, and the undoubted character of the USA as a nation of immigrants, some Americans have always paid much attention to their various supposed ancestries - their Roots.

Much history is used, even by serious historians, to trace the way their national past led to the present. Myths are powerful and survive. In England, the eight hundredth anniversary of Magna Carta in 2015 evoked what seem to me wholly fictitious stories of the special and exemplary character of English liberty. We all need to compare our bits of history with other periods, other areas, and other disciplines in order to make sense of our own. If anyone shows that I have got things wrong, knowledge - at least my knowledge - will be advanced. We need to look hard at words like nation and state and kingdom and country and what we understand by them, so as to begin to distinguish what people in the past meant by whatever words they used, how they organized their societies and governments, how they regarded them, and why they obeyed or did not obey their rulers. Which brings me back to one particular message I would like to leave with my readers: the difference between words, concepts, and phenomena and between our words and concepts and those of the particular bits of the past we are studying. Is the history of nationhood about changes in words, or changes in notions in the minds of those who used them, or in phenomena - that is, the actual society and government of whatever area that they were writing about? Which of the three changed at any point, and does that mean that the others changed too? 


\section{References}

Anderson, Benedict, Imagined Communities: Reflections on the Origin and Spread of Nationalism (London, 1983).

Barnard, Alan, Hunters and Herders of Southern Africa (Cambridge, 1992).

Clastres, Pierre, Society Against the State, trans. Robert Hurley (New York, 1977).

Davies, Robert Rees, The Peoples of Britain and Ireland: I-IV, Transactions of the Royal Historical Society Ser. 6, 4-7 (1994-1997).

Duncan, Archibald A. M., The Nation of Scots and the Declaration of Arbroath, 1320 (London, 1970).

Freedman, Paul, Images of the Medieval Peasant (Stanford, 1999).

Friend, Julius W., Stateless Nations: Western European Regional Nations and the Old Nations (Basingstoke, 2012).

Gat, Azar, Nations: the Long History and Deep Roots of Political Ethnicity and Nationalism (Cambridge, 2013).

Gellner, Ernest, Nations and Nationalism (Oxford, 1983).

Goetz, Hans-Werner, Regnum: zum politischen Denken der Karolingerzeit, Zeitschrift der Savigny-Stiftung für Rechtsgeschichte: Germanistische Abteilung 104 (1987) 110-89.

Grotius, Hugo, Liber de antiquitate reipublicae Batavicae (Leiden, 1610).

Grotius, Hugo, A Treatise of the Antiquity of the Commonwealth of the Battavers which is now the Hollanders, trans. Thomas Woods (London, 1649).

Hirschi, Caspar, The Origins of Nationalism: an Alternative History from Ancient Rome to Early Modern Germany (Cambridge, 2012).

Hobsbawm, Eric, Nations and Nationalism since 1780 (Cambridge, 1990).

Karakasidou, Anastasia. N., Fields of Wheat, Hills of Blood: Passages to Nationhood in Greek Macedonia (Chicago, 1997).

Lapierre, Jean-William, Vivre sans état?: essai sur le pouvoir politique et l'innovation sociale (Paris, 1977).

Lyons, John, Semantics I (Cambridge, 1977).

Miller, William Ian, 'Why is Your Axe so Bloody?: A Reading of Njal's Saga (Oxford, 2014).

Ogden, Charles K. and Richards, Ivor A., The Meaning of Meaning (London, 1923).

Oxford English Dictionary, "people, n.«, OED Online, September 2015. Retrieved November 27, 2015: http://www.oed.com/view/Entry/140404?

Pohl, Walter, Introduction - Strategies of Identification: A Methodological Profile, in: Walter Pohl and Gerda Heydemann (eds.), Strategies of Identification. Ethnicity and Religion in Early Medieval Europe (Turnhout, 2013) 1-52.

Reynolds, Susan, Fiefs and Vassals: the Medieval Evidence Reinterpreted (Oxford, 1994).

Reynolds, Susan, Kingdoms and Communities in Western Europe, 90o-130o, 2nd edition (Oxford, 1997).

Reynolds, Susan, Our Forefathers? Tribes, Peoples and Nations in the Age of Migrations, in: Alexander Callander Murray (ed.), After Rome's Fall: Narrators and Sources of Early Medieval History. Essays presented to Walter Goffart (Toronto, 1998) 17-36. Reprinted in Reynolds, The Middle Ages without Feudalism, XI.

Reynolds, Susan, The Idea of the Nation as a Political Community in: Len Scales and Oliver Zimmer (eds.), Power and the Nation in European History (Cambridge, 2005) 54-66. Reprinted in Reynolds, The Middle Ages without Feudalism, XIV. 
Reynolds, Susan, Before Eminent Domain: Toward a History of Expropriation of Land for the Common Good (Chapel Hill, 2010).

Reynolds, Susan, The Use of Feudalism in Comparative History, in: Benjamin Z. Kedar (ed.), Explorations in Comparative History (Jerusalem, 2009) 191-217. Reprinted in Reynolds, The Middle Ages without Feudalism VI.

Reynolds, Susan, The Middle Ages without Feudalism: Essays in Criticism and Comparison on the Medieval West (Farnham, 2012).

Reynolds, Susan, Vocabularies for Comparative and Interdisciplinary History, in: Reynolds, The Middle Ages without Feudalism, XVII, 1-17.

Scales, Len, The Shaping of German Identity: Authority and Crisis (Cambridge, 2012).

Schmidt-Wiegand, Ruth, Die Bezeichnungen Zunft und Gilde in ihrem historischen und wortgeographischen Zusammenhang, in: Berent Schwineköper (ed.), Gilden und Zünfte: kaufmännische und gewerbliche Genossenschaften im frühen und hohen Mittelalter, Vorträgen und Forschungen 29 (Sigmaringen, 1985) 31-52.

Schmidt-Wiegand, Ruth, Historische Onomasiologie und Mittelalterforschung, Frühmittelalterliche Studien 9 (1975) 49-78.

Smith, Anthony D., The Ethnic Origins of Nations (Oxford, 1986).

Smith, Anthony D., Nationalism: Theory, Ideology, History, 2nd edition (Cambridge, 2010).

Tallis, Raymond, Not Saussure (London, 1988).

Weber, Max, Wirtschaft und Gesellschaft: Grundriß derverstehenden Soziologie, 5th edition (Tübingen, 1980).

Wickham, Chris, Conclusions, in: Walter Pohl and Gerda Heydemann (eds.), Strategies of Identification. Ethnicity and Religion in Early Medieval Europe (Turnhout, 2013) 551-555.

Wipo, Opera, ed. Harry Bresslau, MGH SS rerum Germanicum in usum scholarum [61] (Hannover, 1915).

Woodburn, James, Egalitarian Societies, Man, New Series 17 (1982) 431-451. 